\title{
Multiple Citrus Viroids in Citrus from Japan and Their Ability to Produce Exocortis-Like Symptoms in Citron
}

\author{
Takao Ito, Hiroyuki Ieki, Katsumi Ozaki, Toru Iwanami, Kenji Nakahara, \\ Tatsuji Hataya, Tsutae Ito, Masahiro Isaka, and Takeshi Kano
}

First and seventh authors: Department of Citrus Research, National Institute of Fruit Tree Science, Kuchinotsu, Nagasaki 859-2501, Japan; second author: Department of Grape and Persimmon Research, National Institute of Fruit Tree Science, Akitsu, Hiroshima 729-2494, Japan; third author: Faculty of Horticulture, Minami Kyushu University, Takanabe, Miyazaki 884-0003, Japan; fourth author: National Institute of Fruit Tree Science, Tsukuba, Ibaraki 305-8605, Japan; fifth author: Biotechnology Institute, Akita Prefectural University, Ohgata, Akita 010-0444, Japan; sixth author: Graduate School of Agriculture, Hokkaido University, Sapporo, Hokkaido 060-8589, Japan; eighth author: Yamato Post-entry Quarantine Center, Yokohama Plant Protection Station, Yamato, Kanagawa 242-0006, Japan; and ninth author: Headquaters, National Agricultural Research Organization, Tsukuba, Ibaraki 305-8517, Japan.

Accepted for publication 24 January 2002.

\section{ABSTRACT}

Ito, T., Ieki, H., Ozaki, K., Iwanami, T., Nakahara, K., Hataya, T., Ito, T., Isaka, M., and Kano, T. 2002. Multiple citrus viroids in citrus from Japan and their ability to produce exocortis-like symptoms in citron. Phytopathology 92:542-547.

Sequential polyacrylamide gel electrophoresis analyses showed many viroid-like RNAs in samples collected from citrus trees in Japan. Reverse transcription polymerase chain reaction and sequencing analyses of the amplified fragments verified that they were derived from variants of six citrus viroids, Citrus exocortis viroid (CEVd), Citrus bent leaf viroid (CBLVd) including CVd-I-LSS (a distinct variant of CBLVd), Hop stunt viroid, Citrus viroid III, Citrus viroid IV, and Citrus viroid OS. The samples induced symptoms with variable severity in Arizona 861-S1 'Etrog' citrons (Citrus medica L.) likely due to the varying accumulation patterns produced by the different viroids. Some of the symptoms caused by the samples harboring the citrus viroids other than CEVd were as severe as those caused by CEVd. Some source citrus trees showing the severe bark scaling characteristic of exocortis disease in trifoliate orange (Poncirus trifoliata (L.) Raf.) rootstocks contained only citrus viroids other than CEVd in complex. This indicates that certain exocortis-like diseases in Japan were caused by some combination of citrus viroids not including CEVd.

Additional keywords: cachexia, nucleotide sequence, variation.
Viroids are the smallest known plant pathogens. They consist of unencapsidated, circular, and single-stranded RNA with 246 to 463 nucleotides (nt). Many citrus viroid variants have been catalogued using sequential polyacrylamide gel electrophoresis (sPAGE) (5). Nucleotide sequencing has been utilized to classify them $(1,3,7,9-12,14,16-19,21,24,25,26)$ into six citrus viroids, Citrus exocortis viroid (CEVd), Citrus bent leaf viroid (CBLVd: formerly called citrus viroid [CVd]-I) including CVd-I-LSS (low sequence similarity: a distinct variant of CBLVd, or a possible new species [11]), Hop stunt viroid (HSVd: formerly called CVdII), Citrus viroid III (CVd-III), Citrus viroid IV (CVd-IV), and Citrus viroid OS (CVd-OS). CBLVd including CVd-I-LSS, CVdIII, and CVd-OS are classified in the genus Apscaviroid, while CEVd, HSVd, and CVd-IV are classified in the genera Pospiviroid, Hostuviroid, and Cocadviroid, respectively $(7,11,12)$.

Some citrus viroids affect citrus trees grafted on trifoliate orange (Poncirus trifoliata (L.) Raf.) rootstocks $(2,6,8,22,25)$. In particular, CEVd is the causal agent of citrus exocortis disease, the symptoms of which are bark scaling on trifoliate orange rootstocks and stunting of the entire tree (6). On the other hand, some HSVd variants are causal agents of citrus cachexia disease, which have not been found in Japan, and can severely affect sensitive hosts such as mandarins (Citrus reticulata Blanco) $(6,14,20,21)$. However, whereas citrus viroids can be influential in citriculture in Japan where trifoliate oranges and mandarins are the most

Corresponding author: T. Ito; E-mail address: itotaka@affrc.go.jp

Publication no. P-2002-0313-01R

(c) 2002 The American Phytopathological Society popular rootstocks and cultivars, respectively, the distribution of citrus viroids in Japan has been only fragmentarily investigated $(9,11,12,15,16,24,27)$. Therefore, in this study, we examined the presence of these viroids in citrus trees within Japan by means of SPAGE, reverse transcription polymerase chain reaction (RTPCR), and sequencing. We determined that multiple citrus viroids were present in single trees and compared the symptoms produced by these infections to those produced by exocortis disease in Japan.

\section{MATERIALS AND METHODS}

Plant samples. Plant samples used in the present study were collected from diseased, declining, or stunting citrus trees planted in certain horticultural experimental stations or commercial orchards in every representative citrus growing area in Japan (Table 1). Severe bark scaling characteristic of exocortis disease was observed in the trifoliate orange rootstocks of some of the source citrus trees during sample collection. All the samples were graftinoculated into Arizona 861-S1 'Etrog' citrons (C. medica L.) on rough lemon (C. jambhiri Lush.) rootstocks, and maintained in a greenhouse.

Extraction of nucleic acids and SPAGE analysis. Extraction of nucleic acids from samples for sPAGE was conducted as described by Ito et al. (11) in a fifth scale with $30 \mathrm{~g}$ of leaves and stems of the citrons as the primary extract sources. When the citron tissues were not sufficient for $30 \mathrm{~g}$, extract of the suckers of the rough lemon rootstock budded with the citron was added. However, in this case, the same volumes described above sometimes made further purification difficult. Therefore, after phenol/ 
chloroform extraction, approximately one-half volume of the supernatant was collected and diluted with one-half volume of extraction buffer.

Extracted nucleic acids were analyzed using an sPAGE system following the method described by Ito et al. (11) with slight modification. A second electrophoresis under the denaturing conditions of sPAGE was run for $3 \mathrm{~h}$ after the xylene cyanol tracking dye had left the gel. After the electrophoresis, the viroid-like RNAs were viewed by staining them with Silver Stain 'Daiichi' (Daiichi Pure Chemicals, Tokyo, Japan), following the manufacturer's instructions.

RT-PCR, and cloning and sequencing of the amplified fragments. RT-PCR to detect CEVd, CBLVd, CVd-I-LSS, CVd-
OS, HSVd, CVd-III, and CVd-IV was carried out following the method described by Ito et al. (11) using a primer pair designed to amplify the full length of each of the target viroids (Table 2). Thermal cycling was performed for 30 to 35 cycles. Amplified fragments from RT-PCR were viewed after electrophoreses in $6 \%$ polyacrylamide slab gel $(8 \times 10 \times 0.1 \mathrm{~cm})$ at $80 \mathrm{~V}$ for $1 \mathrm{~h} 45 \mathrm{~min}$ in TBE buffer ( $89 \mathrm{mM}$ Tris, $89 \mathrm{mM}$ boric acid, $2 \mathrm{mM}$ EDTA, $\mathrm{pH}$ 8.3 ) by silver staining as described above. The amplified fragments derived from variants whose nucleotide sequences were not determined $(9,11,12,16)$ were cloned and sequenced primarily using the method described by Ito et al. (11). Some sequencing was conducted using Taq DNA polymerase and -21M13 dye primer or M13 reverse dye primer (Applied Biosystems, Foster

TABLE 1. Samples from source citrus trees used in this study, the viroid profiles, and the symptoms induced in Arizona 861-S1 'Etrog' citrons at 8 months postinoculation

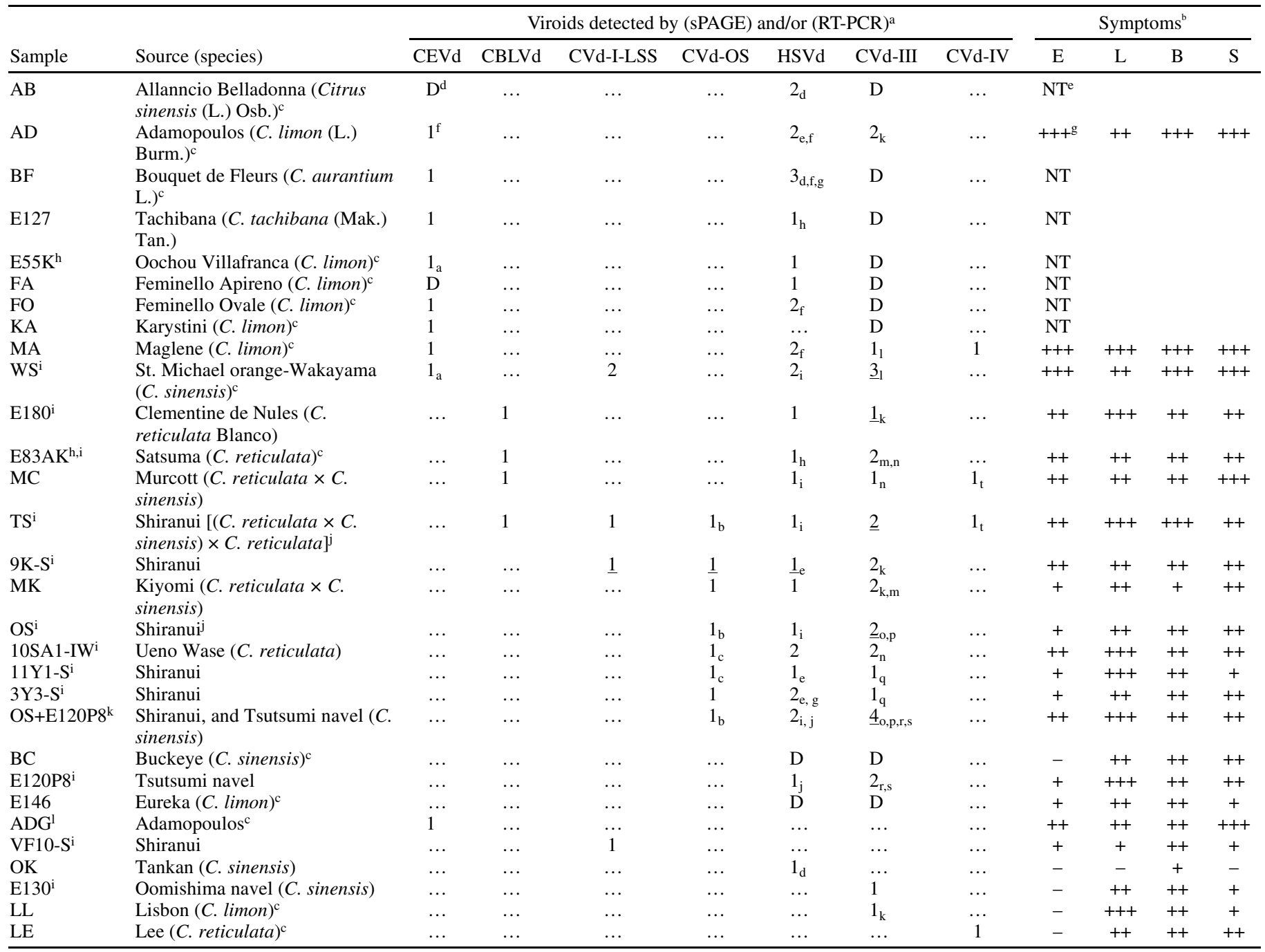

$\mathrm{a}($ sPAGE) $=$ sequential polyacrylamide gel electrophoresis. $(\mathrm{RT}-\mathrm{PCR})=$ reverse transcription-polymerase chain reaction. CEVd $=$ Citrus exocortis viroid, CBLVd = Citrus bent leaf viroid formerly called citrus viroid (CVd)-I including CVd-I-LSS (low sequence similarity: a distinct variant of CBLVd, or a possible new species), CVd-OS = Citrus viroid OS, HSVd = Hop stunt viroid, CVd-III = Citrus viroid III, CVd-IV = Citrus viroid IV. CBLVd, CVd-I-LSS, and CVd-OS could not be clearly distinguished from one another using sPAGE because of their similar molecular sizes $(11,12)$.

${ }^{\mathrm{b}} \mathrm{E}=$ epinasty; $\mathrm{L}=$ leaf bending; $\mathrm{B}=$ midvein and petiole browning; $\mathrm{S}=$ stunting.

c Citrus trees grown in fields in Department of Citrus Research, National Institute of Fruit Tree Science, Okitsu, Shizuoka.

${ }^{\mathrm{d}} \mathrm{D}=$ detected by both of sPAGE and RT-PCR. $\ldots=$ detected by neither sPAGE nor RT-PCR.

e Not tested.

${ }^{\mathrm{f}}$ Numbers of variants whose nucleotide sequences were determined are indicated. Numbers less than those of viroid bands detected by sPAGE are underlined.

Variants with the identical nucleotide sequences are indicated with the same letters $\left(_{\mathrm{a}-\mathrm{t}}\right)$ at the foot.

g Symptom severity from the average of three plants after 8 months under controlled temperatures $\left(28\right.$ to $\left.32^{\circ} \mathrm{C}\right) .-=$ no reaction to $+++=$ severe symptom.

${ }^{\text {h }}$ Samples obtained by reciprocally cutting the source citrus tree and citron stems with a knife.

${ }^{\text {i }}$ Samples also described in previous reports $(9,11,12,15,16)$.

j Citrus trees grown in fields in Department of Citrus Research, National Institute of Fruit Tree Science, Kuchinotsu, Nagasaki.

${ }^{k}$ Coinoculated with the OS and E120P8 samples.

${ }^{1}$ Sample obtained by cutting a citron stem with a knife contaminated by cutting Gynura aurantiaca previously inoculated with the AD sample. 
City, CA) employing a DNA sequencer (373A, Applied Biosystems). More than three cloned fragments were always sequenced to determine the nucleotide sequence of each variant. The determined sequences were analyzed using GENETYX software version 10.1 (Software Development Co., Ltd., Tokyo, Japan).

Biological indexing. Each of the plant samples was graftinoculated into three Arizona 861-S1 'Etrog' citrons on rough lemon rootstocks growing under controlled temperatures (28 to $32^{\circ} \mathrm{C}$ ). Symptoms such as epinasty, leaf bending, midvein and petiole browning, and stunting shown in the citrons were evaluated 8 months after graft-inoculation (4).

\section{RESULTS}

SPAGE analysis, RT-PCR, and nucleotide sequencing analysis. SPAGE analyses of the nucleic acid extracts from the samples revealed various viroid-like RNAs (Table 1 ). To verify the presumed identities of the viroids from samples analyzed by sPAGE, RT-PCR was conducted on all samples to detect CEVd, CBLVd, CVd-I-LSS, CVd-OS, HSVd, CVd-III, and CVd-IV. Amplified fragments with molecular sizes specific for each were observed in silver-stained gels after electrophoreses (data not shown). Nonspecific bands were seldom observed, and no fragments were detected from samples used as healthy controls (data not shown). The nucleotide sequencing analyses of most of the amplified fragments showed various variants derived from CEVd, CBLVd, CVd-I-LSS, CVd-OS, HSVd, CVd-III, and CVd-IV (Table 1). Although cloned fragments with nucleotide changes were sometimes obtained from some samples, the sequences were ignored unless three independent clones or more with identical sequences were obtained. Two variants or more were sometimes found in one sample, and some variants were identical to those in other samples. In most cases, the molecular sizes corresponded to those of the viroid-like RNAs detected using sPAGE (Table 1). The combination of CEVd, HSVd, and CVd-III was the most commonly detected combination from samples derived from the introduced cultivars such as lemons and oranges in the Department of Citrus Research, National Institute of Fruit Tree Science, Okitsu, Shizuoka (Table 1). On the other hand, the combination of CVd-OS, HSVd, and CVd-III was the most commonly detected combination from the other samples. Except for CEVd in the ADG sample and CVd-I-LSS in the VF10-S sample, both of which were artificially isolated, only HSVd, CVd-III, and CVd-IV were detected solely from the OK, E130, and LE samples, respectively.
Figure 1 shows the variation among the nucleotide sequences of the variants of CEVd, CBLVd including CVd-I-LSS, CVd-OS, HSVd, CVd-III, and CVd-IV. Variable nucleotide changes among the variants were dispersed in some of the structural domains. Some of the nucleotide sequences of the HSVd and CVd-III variants were identical to those of variants previously reported $(10,19$, 21,25). The HSVd variant E55K had the same nucleotide sequence as CVd-IIc causing severe cachexia reaction (21). Also, the HSVd variants $\mathrm{AB}_{2}, \mathrm{AD}_{2}, \mathrm{BF}_{3}, \mathrm{FA}, \mathrm{FO}_{1,2}, \mathrm{MA}_{2}$, and $\mathrm{WS}_{2}$ showed all or some of the six nucleotide changes associated with transition from noncachexia-inducing CVd-IIa to cachexia variants (20) (Fig. 1). All these HSVd variants were derived from source citrus trees such as lemons and oranges in the Department of Citrus Research, National Institute of Fruit Tree Science, Okitsu, Shizuoka (Table 1).

The nucleotide sequences of the CEVd variants $\mathrm{AD}, \mathrm{ADG}, \mathrm{BF}$, E127, E55K, FO, KA, and MA, the CBLVd variants E83AK (11) and MC, the CVd-I-LSS variants TS, $\mathrm{WS}_{1,2}$, and 9K-S (11), the CVd-OS variants MK, TS, 10SA1-IW, 3Y3-S, and 9K-S, the HSVd variants $\mathrm{AB}_{2}, \mathrm{AD}_{1,2}, \mathrm{BF}$ (1: omitted), E120P8, E127, E180, FA, FO ( ${ }_{1}$ : omitted), MA ( ${ }_{1}$ : omitted), MK, $\mathrm{WS}_{1,2}$, and 10SA1$\mathrm{IW}_{1,2}$, the CVd-III variants $\mathrm{AD}_{1,2}, \mathrm{E} 120 \mathrm{P} 8_{1,2}, \mathrm{E} 130, \mathrm{MA}, \mathrm{OS}_{1,2}$, $\mathrm{TS}_{1,2}, \mathrm{WS}_{1,2}, 10 \mathrm{SA} 1-\mathrm{IW}\left({ }_{2}\right.$ : omitted), and 11Y1-S, and the CVd-IV variants LE, MA, and MC (Fig. 1) have been deposited in GenBank (Accession Nos. AB054592-AB054641 and AB055634).

Biological indexing. Symptoms induced by each of the samples in the Arizona 861-S1 'Etrog' citrons at 8 months postinoculation are summarized in Table 1 . The samples showed symptoms with variable severity in the citrons likely due to the varying accumulation patterns induced by different viroids. For example, coinoculation with the E120P8 and OS samples into the citrons (OS+E120P8) showed more severe symptoms than those expressed by the OS sample alone (Table 1). Consequently, some of the samples harboring citrus viroids other than CEVd in complex could cause symptoms as severe as those seen in the samples harboring CEVd.

Severe bark scaling in trifoliate orange rootstocks of some source citrus trees. Figure 2 shows examples of severe bark scaling associated with stunting of the entire tree observed in the trifoliate orange rootstocks of the source trees of the MC, TS, and E120P8 samples. No CEVd was detected from any of these samples (Table 1). Only HSVd and CVd-III were detected from all of them, whereas CBLVd and CVd-IV were additionally detected from the MC and TS samples, and CVd-I-LSS and CVdOS was detected, as well, from the TS sample (Table 1). Trifoliate

TABLE 2. Primers used in the uniplex reverse transcription-polymerase chain reaction

\begin{tabular}{|c|c|c|c|c|}
\hline Name & Sequence $\left(5^{\prime}-3^{\prime}\right)$ & Target $^{\mathrm{a}}$ & Position & Reference $^{\mathrm{b}}$ \\
\hline CEV 20-mer primer $(-)^{\mathrm{c}}$ & CCCTGAAGGACTTCTTCCCC & CEVd & $71-90$ & Yang et al. (28) \\
\hline CEV 24-mer primer (+) & ATCCCCGGGGAAACCTGGAGGAAG & & $91-114$ & \\
\hline oC-CEVd (-) & CGGGGATCCCTGAAGGACTT & CEVd & $77-96$ & Ben-Shaul et al. (3) \\
\hline CBLV-CM (-) & ACGACCAGTCAGCTCCTCTG & CBLVd & $75-94$ & Ito et al. (11) \\
\hline CBLV-CP (+) & CGTCGACGAAGGCTCGTCAGCT & & $95-116$ & \\
\hline CB2-CM (-) & ACGACCGCTCAGTCTCCTCT & CVd-I-LSS & $76-95$ & Ito et al. (11) \\
\hline CB2-CP (+) & CGTCGACGAAGGCTCCTCAGTC & & $96-117$ & \\
\hline HSV 19-mer primer $(-)$ & GGCTCCTTTCTCAGGTAAG & HSVd & $60(61)-78(79)$ & Yang et al. (28) \\
\hline HSV 25-mer primer (+) & CCGGGGCAACTCTTCTCAGAATCCA & & $79(80)-103(104)$ & \\
\hline CVIII-CM (-) & TCGACGACGACAGGTAAGTT & CVd-III & $72-91$ & Rakowski et al. (19) \\
\hline CVIII-CP $(+)$ & CGAAGGCAGCTAAGTTGGTGA & & $92-112$ & \\
\hline CVIV-CM (-) & GGATCCCTCTTCAGGTATGT & CVd-IV & $48-67$ & Puchta et al. (18) \\
\hline CVIV-CP $(+)$ & CCGGGGAAATCTCTTCAGACTC & & $68-89$ & \\
\hline
\end{tabular}

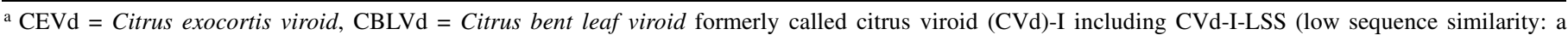
distinct variant of CBLVd, or a possible new species), CVd-OS = Citrus viroid OS, HSVd = Hop stunt viroid, CVd-III = Citrus viroid III, CVd-IV = Citrus viroid IV.

b References to primers or viroid sequences used to design the primer.

c $(-)=$ antisense primer, $(+)=$ sense primer.
} 


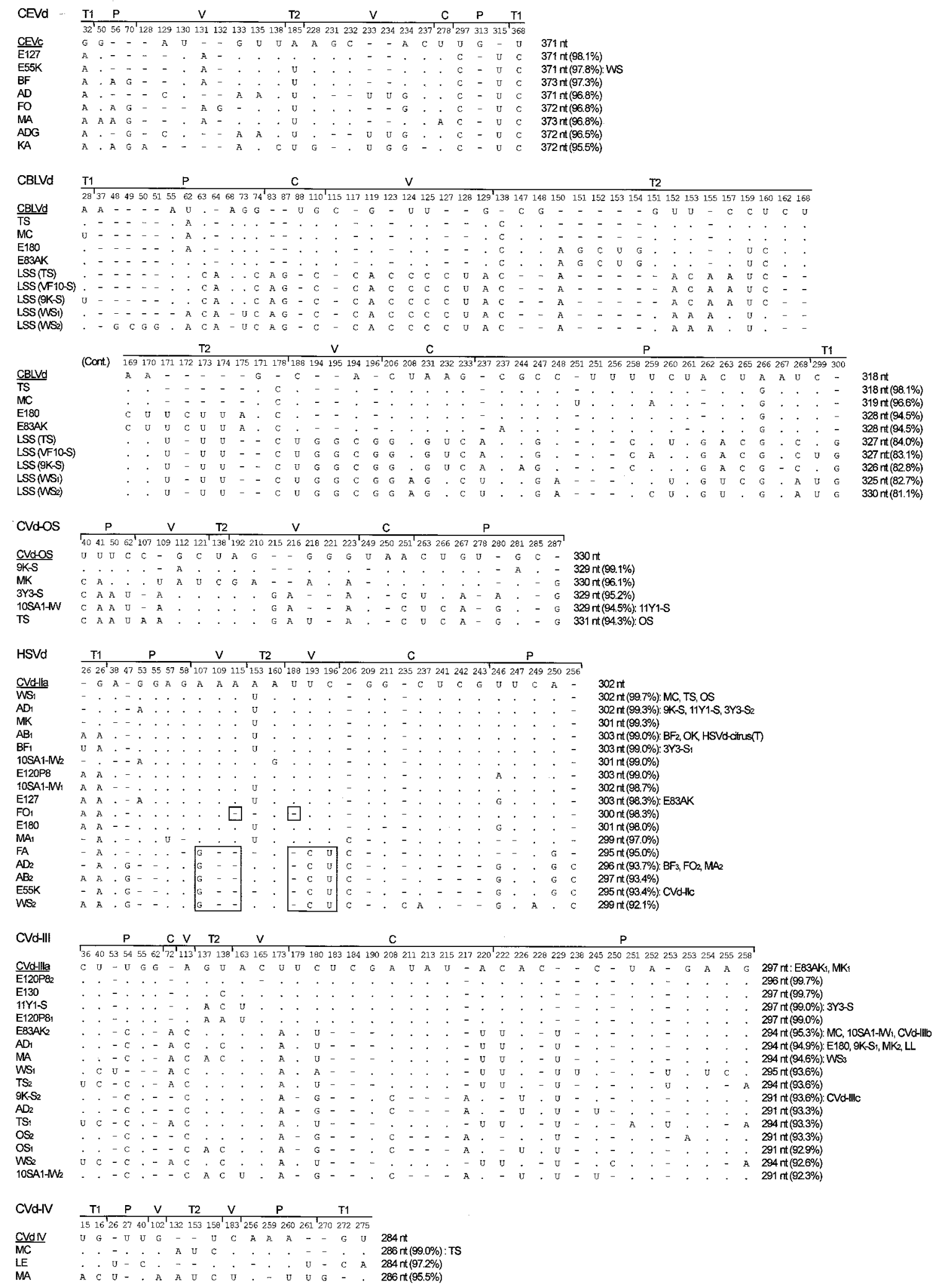

Fig. 1. Nucleotide changes from a representative variant (underlined) of Citrus exocortis viroid (CEVd [CEVc] \{26\}), Citrus bent leaf viroid (CBLVd [1]), Citrus viroid OS (CVd-OS [12]), Hop stunt viroid (HSVd [CVd-IIa] \{21\}), Citrus viroid III (CVd-III [CVd-IIIa] \{19\}), or Citrus viroid IV (CVd-IV [CVd IV] $\{18\})$ to each of the variants derived from the samples. LSS in CBLVd variants mean the CVd-I-LSS variants. Following the nucleotide changes, the molecular size of the variant, nucleotide sequence identity with the representative variant, and the other variants with identical nucleotide sequences are indicated. Variants are listed in order of nucleotide sequence identity. More than two HSVd or CVd-III variants derived from one sample are numbered (1-3, at the foot) generally in descending molecular size. HSVd-citrus(T) (10), CVd-IIc (21), CVd-IIIb (19), and CVd-IIIc (25) were described previously. Nucleotide sequences of the CBLVd variants TS, E180, and E83AK, all the CVd-I-LSS variants, the CVd-OS variants OS, and the CVd-III variants E83AK 1,2 were also described previously $(9,11,12,16)$. Dots indicate nucleotides identical to those of the representative variants, and bars denote gaps. Nucleotide changes associated with those from non-cachexia-inducing CVd-IIa to cachexia-inducing variants (20) are boxed. Approximately arranged ranges of the five structural domains, C (central), P (pathogenic), V (variable), T1 (left terminal), and T2 (right terminal), of each of the citrus viroids are indicated with symbols and lines (13). 
orange rootstocks of other graft-propagated trees of the source trees of the MC and TS samples commonly showed severe bark scaling (data not shown). On the other hand, the source tree of the E120P8 sample had not been graft-propagated and only this single tree showed severe bark scaling in its trifoliate orange rootstock. Trifoliate orange rootstocks of the source trees of the AD, MA, and WS samples harboring CEVd showed severe bark scaling as well (data not shown). The rootstocks of the other source trees were not checked, or bark scaling was not observed in them. Bark scaling was usually not observed in viroid-free trifoliate orange rootstocks. Figure 2D shows an example of the absence of bark scaling in the trifoliate orange rootstock of a viroid-free citrus tree whose tree age and environmental condition were similar with the source tree of the TS sample. Trifoliate orange rootstocks from the viroid-free graft-propagated trees showed no bark scaling as well (data not shown). The MC, TS, and E120P8 samples were indexed by reciprocal stem-slash inoculation into Gynura aurantiaca, respectively, which did not result in symptoms associated with CEVd despite clear symptoms caused by all the samples harboring CEVd (data not shown).

\section{DISCUSSION}

The results of the RT-PCRs and subsequent sequence analysis of these products verified conclusions reached after sPAGE regarding the identities of citrus viroids in samples from citrus trees. Although a previous dot blot hybridization test showed positive signals of CEVd and CBLVd from the 3Y3-S sample (16), neither CEVd nor CBLVd were detected from the 3Y3-S sample (Table 1). Because another dot blot hybridization using a CEVd probe was also unable to detect CEVd from the 3Y3-S sample (data not
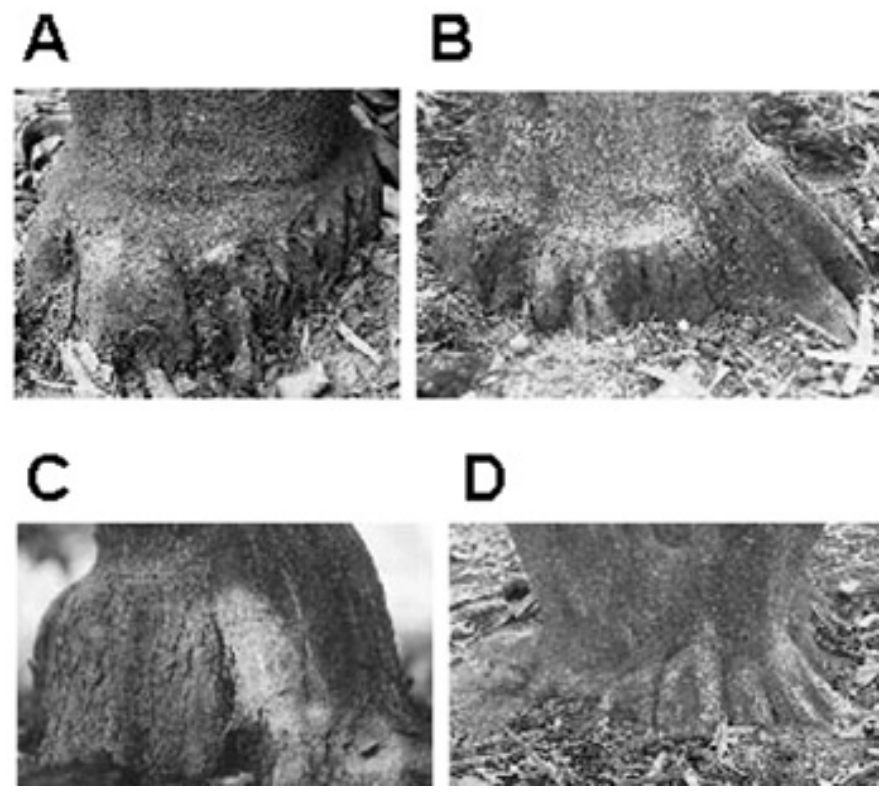

Fig. 2. Conditions of trifoliate orange rootstocks of some of the source citrus trees and a viroid-free trifoliate orange rootstock. A, Severe bark scaling in the rootstock of the 21-year-old 'Murcott' tree, the source of the MC sample harboring Citrus bent leaf viroid (CBLVd) formerly called citrus viroid (CVd)-I, Hop stunt viroid (HSVd), Citrus viroid III (CVd-III), and Citrus viroid IV (CVd-IV). B, Severe bark scaling in the rootstock of the 26-yearold orange tree at 8 years after top grafting of 'Shiranui' budwood, the source of the TS sample harboring CBLVd, CVd-I-LSS (low sequence similarity: a distinct variant of CBLVd, or a possible new species), Citrus viroid OS (CVd-OS), HSVd, CVd-III, and CVd-IV. C, Severe bark scaling in the rootstock of the 15-year-old 'Tsutsumi navel' tree, the source of the E120P8 sample harboring HSVd and CVd-III. D, No bark scaling in the rootstock of the 25-year-old Ponkan (C. reticulata) tree harboring no citrus viroids, which was grown in an adjoining section of the same field as the tree shown in B. shown), the previous signals may have resulted from false positive reactions in dot blots. Nevertheless, all the results in this study showed that, in Japan, various citrus viroids have a complex distribution. CEVd, HSVd, and CVd-III in complex were most broadly detected from the introduced cultivars such as lemons and oranges in the Department of Citrus Research, National Institute of Fruit Tree Science, Okitsu, Shizuoka (Table 1). On the other hand, CVd-OS, HSVd, and CVd-III in complex were most broadly detected from the domestic cultivar, 'Shiranui' (Table 1). Some of the CEVd, CBLVd, HSVd, CVd-III, or CVd-IV variants had similar or identical nucleotide sequences to those in other countries $(1,10,18,19,21,25,26)$ (Fig. 1), suggesting that those variants may have been imported from or exported to those countries together via citrus budwood (27). CVd-I-LSS and CVd-OS prevalent in Japan might be found in other countries as well. Surprisingly, the HSVd variants having similar or identical nucleotide sequences to cachexia-inducing variants $(20,21)$ were identified (Fig. 1), whereas no cachexia disease has been reported in Japan. However, because all these HSVd variants were derived from nonsensitive citrus hosts (6) (Table 1), no typical cachexia symptoms were observed. Biological indexing using the indicator host, 'Parson's Special' mandarin (C. reticulata) $(6,20,21)$, is now in progress to clarify whether cachexia disease is present in Japan.

Some nucleotide changes can affect the pathogenicity of a viroid, a phenomenon, which has also been observed in citrons infected with certain citrus viroid variants $(14,17,25,26)$. Also, some combination of nucleotide changes in structural domains can be correlated with symptoms such as epinasty, stunting, and veinal necrosis (23). The citrus viroid variants found in this study had variable nucleotide changes dispersed in some of the structural domains (Fig. 1), which could reflect the variation of the symptom expressions in the citrons observed even among the samples having similar viroid profiles (Table 1). On the whole, symptoms expressing variable severity in the citrons were likely due to the varying accumulation patterns caused by the different viroids (Table 1), and some combination of citrus viroids other than CEVd induced symptoms as severe as those caused by CEVd. This finding indicates that citrus viroids other than CEVd in mixed infection produce severe exocortis-like symptoms in trifoliate orange rootstocks. In fact, a combination of viroids with 330 , 299, 295, and 284 nt that could be CBLVd, HSVd, CVd-III, and CVd-IV, respectively (2), produces severe bark scaling characteristic of exocortis disease in trifoliate orange rootstocks (8). The analyses of the MC and TS samples harboring CBLVd, HSVd, CVd-III, and CVd-IV in common also showed that the combination could be associated with some exocortis-like diseases in Japan. On the other hand, the analyses of the E120P8 sample harboring only HSVd and CVd-III showed that only HSVd and CVdIII in complex could produce exocortis-like symptoms in trifoliate orange rootstocks. However, another combination of HSVd and CVd-III with CBLVd in complex could not induce bark scaling but only bark striations and mild bark cracks in trifoliate orange rootstocks (22). To clarify which viroid combination can produce exocortis-like symptoms, investigations using citrus trees inoculated with various mixtures of pure viroids grown in the same field should be performed. In any event, in Japan where trifoliate orange rootstocks are commonly used and multiple citrus viroids can be broadly present in single trees, it is a matter of some concern that exocortis-like diseases could be caused by citrus viroids other than CEVd in complex.

\section{ACKNOWLEDGMENTS}

We thank all persons who provided us with the citrus viroid sources and assisted us in their collection; K. Muramoto, T. Yoshida, and T. Takahara for their invaluable information; and Y. Kondo and S. Taguchi for sequencing the viroid clones. Contribution No. 1246 of National Institute of Fruit Tree Science. 


\section{LITERATURE CITED}

1. Ashulin, L., Lachman, O., Hadas, R., and Bar-Joseph, M. 1991. Nucleotide sequence of a new viroid species, citrus bent leaf viroid (CBLVd) isolated from grapefruit in Israel. Nucleic Acids Res. 19:4767.

2. Bar-Joseph, M. 1993. Citrus viroids and citrus dwarfing in Israel. Acta Hortic. 349:271-276

3. Ben-Shaul, A., Guang, Y., Mogilner, N., Hadas, R., Mawassi, M., Gafny, R., and Bar-Joseph, M. 1995. Genomic diversity among populations of two citrus viroids from different graft-transmissible dwarfing complexes in Israel. Phytopathology 85:359-364.

4. Duran-Vila, N., Pina, J. A., and Navarro, L. 1993. Improved indexing of citrus viroids. Pages 202-211 in: Proc. Conf. Int. Organ. Citrus Virol., 12th. IOCV, Riverside, CA.

5. Duran-Vila, N., Roistacher, C. N., Rivera-Bustamante, R., and Semancik, J. S. 1988. A definition of citrus viroid groups and their relationship to the exocortis disease. J. Gen. Virol. 69:3069-3080.

6. Duran-Vila, N., Semancik, J. S., and Broadbent, P. 2000. Viroid diseases, cachexia, and exocortis. Pages 51-54 in: Compendium of Citrus Diseases. 2nd ed. The American Phytopathological Society, St. Paul, MN.

7. Flores, R., Randles, J. W., Bar-Joseph, M., and Diener, T. O. 1998. A proposed scheme for viroid classification and nomenclature. Arch. Virol. 143:623-629.

8. Hadas, R., and Bar-Joseph, M. 1991. Variation in tree size and rootstock scaling of grapefruit trees inoculated with a complex of citrus viroids. Pages 240-243 in: Proc. Conf. Int. Organ. Citrus Virol., 11th. IOCV, Riverside, CA.

9. Hataya, T., Nakahara, K., Ohara, T., Ieki, H., and Kano, T. 1998. Citrus viroid Ia is a derivative of citrus bent leaf viroid (CVd-Ib) by partial sequence duplications in the right terminal region. Arch. Virol. 143:971-980.

10. Hsu, Y.-H., Chen, W., and Owens, R. A. 1994. Nucleotide sequence of a hop stunt viroid variant isolated from citrus growing in Taiwan. Virus Genes 9:193-195.

11. Ito, T., Ieki, H., and Ozaki, K. 2000. A population of variants of a viroid closely related to citrus viroid-I in citrus plants. Arch. Virol. 145:21052114.

12. Ito, T., Ieki, H., Ozaki, K., and Ito, T. 2001. Characterization of a new citrus viroid species tentatively termed Citrus viroid OS. Arch. Virol. 146:975-982.

13. Keese, P., and Symons, R. H. 1985. Domains in viroids: Evidence of intermolecular RNA rearrangements and their contribution to viroid evolution. Proc. Natl. Acad. Sci. USA. 82:4582-4586.

14. Levy, L., and Hadidi, A. 1993. Direct nucleotide sequencing of PCRamplified DNAs of the closely related citrus viroids IIa and IIb (cachexia). Pages 180-186 in: Proc. Conf. Int. Organ. Citrus Virol., 12th.
IOCV, Riverside, CA.

15. Nakahara, K., Hataya, T., and Uyeda, I. 1999. A simple, rapid method of nucleic acid extraction without tissue homogenization for detecting viroids by hybridization and RT-PCR. J. Virol. Methods 77:47-58.

16. Nakahara, K., Hataya, T., Uyeda, I., and Ieki, H. 1998. An improved procedure for extracting nucleic acids from citrus tissues for diagnosis of citrus viroids. Ann. Phytopathol. Soc. Jpn. 64:532-538.

17. Owens, R. A., Thompson, S. M., Feldstein, P. A., and Garnsey, S. M. 1999. Effects of natural sequence variation on symptom induction by citrus viroid III. Ann. Appl. Biol. 134:73-80.

18. Puchta, H., Ramm, K., Luckinger, R., Hadas, R., Bar-Joseph, M., and Sänger, H. L. 1991. Primary and secondary structure of citrus viroid IV (CVd IV), a new chimeric viroid present in dwarfed grapefruit in Israel. Nucleic Acids Res. 19:6640.

19. Rakowski, A. G., Szychowski, J. A., Avena, Z. S., and Semancik, J. S. 1994. Nucleotide sequence and structural features of the group III citrus viroids. J. Gen. Virol. 75:3581-3584.

20. Reanwarakorn, K., and Semancik, J. S. 1998. Regulation of pathogenicity in hop stunt viroid-related group II citrus viroids. J. Gen. Virol. 79:3163-3171.

21. Reanwarakorn, K., and Semancik, J. S. 1999. Correlation of hop stunt viroid variants to cachexia and xyloporosis diseases of citrus. Phytopathology 89:568-574.

22. Roistacher, C. N., Bash, J. A., and Semancik, J. S. 1993. Distinct disease symptoms in Poncirus trifoliata induced by three citrus viroids from three specific groups. Pages 173-179 in: Proc. Conf. Int. Organ. Citrus Virol., 12th. IOCV, Riverside, CA.

23. Sano, T., Candresse, T., Hammond, R. W., Diener, T. O., and Owens, R. A. 1992. Identification of multiple structural domains regulating viroid pathogenicity. Proc. Natl. Acad. Sci. USA 89:10104-10108.

24. Sano, T., Hataya, T., and Shikata, E. 1988. Complete nucleotide sequence of a viroid isolated from Etrog citron, a new member of hop stunt viroid group. Nucleic Acids Res. 16:347.

25. Semancik, J. S., Rakowski, A. G., Bash, J. A., and Gumpf, D. J. 1997. Application of selected viroids for dwarfing and enhancement of production of 'Valencia' orange. J. Hortic. Sci. 72:563-570.

26. Semancik, J. S., Szychowski, J. A., Rakowski, A. G., and Symons, R. H. 1993. Isolates of citrus exocortis viroid recovered by host and tissue selection. J. Gen. Virol. 74:2427-2436.

27. Yamada, S., and Tanaka, H. 1972. Damage from exocortis in Japan. Pages 99-101 in: Proc. Conf. Int. Organ. Citrus Virol., 5th. University of Florida Press, Gainesville.

28. Yang, X., Hadidi, A., and Garnsey, S. M. 1992. Enzymatic cDNA amplification of citrus exocortis and cachexia viroids from infected citrus hosts. Phytopathology 82:279-285. 